\title{
First report of stubby root nematode, Paratrichodorus teres (Nematoda: Trichodoridae) from Iran
}

\author{
R. Heydari • Z. Tanha Maafi • F. Omati • W. Decraemer
}

Received: 8 October 2013 / Accepted: 20 March 2014 / Published online: 4 April 2014

(C) Australasian Plant Pathology Society Inc. 2014

\begin{abstract}
During a survey of plant-parasitic nematodes in fruit tree nurseries in Iran, a species of the genus Paratrichodorus from the family Trichodoridae was found in the rhizosphere of apricot seedlings in Shahrood, central Iran, then subsequently in Karaj orchards. Morphological and morphometric characters of the specimens were in agreement with $P$. teres. The D2/D3 expansion fragment of the large subunit (LSU) of rRNA gene of the nematode was also sequenced. $P$. teres is considered an economically important species in agricultural crop, worldwide. This is the first report of the occurrence of $P$. teres in Iran.
\end{abstract}

Keywords Apricot · Fruit tree nursery · Iran ·

Paratrichodorus teres

Trichodorid nematodes are root ectoparasites, usually aggregating at the tip of the growing root. Upon direct feeding they cause abnormally stunted roots on host plants, a symptom that gave them the name of "stubby root" nematodes. However, the main economic importance of trichodorids lies in the fact that several species of

R. Heydari $(\bowtie)$

Department of Plant Protection, College of Agriculture and Natural Resources, University of Tehran, Karaj, Iran

e-mail: rheydari@ut.ac.ir

\section{Z. T. Maafi}

Iranian Research Institute of Plant Protection, Tehran, Iran

F. Omati

Agricultural and Natural Resources Center of Shahroud, Shahroud, Iran

W. Decraemer

Royal Belgian Institute of Natural Sciences, Brussels, Belgium

W. Decraemer

Department of Biology, Ghent University, Ghent, Belgium
Trichodorus, Nanidorus and Paratrichodorus are natural vectors of the plant Tobraviruses occurring worldwide (Taylor and Brown 1997; Decraemer and Geraert 2006).

Eight species of the Trichodoridae family have so far been reported from Iran: Trichodorus orientalis (De Waele and Hashim 1983), T. persicus (De Waele and Sturhan 1987), T. gilanensis, T. primitivus, Paratrichodorus porosus, $P$. tunisiensis (Maafi and Decraemer 2002), T. arasbaranensis (Zahedi et al. 2009) and P. minor (now Nanidorus minor) (Pourjam et al. 2011).

Several species were detected in a survey conducted on plant-parasitic nematodes in fruit tree nurseries. Among them, a nematode population belonging to Trichodoridae was observed in the rhizosphere of apricot seedlings in Shahroood, Semnan province, central Iran, that was subsequently identified as $P$. teres (Hooper, 1962) Siddiqi, 1974. Another population of the nematode was also recovered from the rhizosphere of peach seedlings in Karaj, Alborz province, Iran.

Soil samples were collected from 10 to $40 \mathrm{~cm}$ depth of the rhizosphere of fruit tree nurseries with weed vegetation. Nematodes were extracted from soil by a centrifugal flotation technique (Jenkins 1964), fixed in heated TAF (triethanolamine $2 \mathrm{ml}$, formaldehyde $7 \mathrm{ml}$ and distilled water $91 \mathrm{ml}$ ), transferred to dehydrated glycerine and mounted in dehydrated glycerine on glass slides (De Grisse 1969). The specimens were studied using a Olympus BH-2 light microscope provided with a drawing tube. The light microscopic photographs were taken with a digital camera linked to a computer.

Total DNA was extracted from hand-picked nematodes, according to Tanha Maafi et al. (2003). The forward D2A (5'-ACAAGTACCGTGAGGGAAAGTTG-3') and reverse D3B (5'-TCGGAAGGAACCAGCTACTA-3') primers (Subbotin et al. 2006) were used for amplification and sequencing of the fragment of the large subunit 
of rRNA gene. After purification of PCR products from the agarose gel slices using QIAquick gel Extraction Kit (Qiagen), the region was sequenced using standard procedures.

\section{Paratrichodorus teres (Hooper, 1962) Siddiqi, 1974}

Measurements of Females; Shahrood population $(n=25)$ : $\mathrm{L}=740 \pm 63.7 \quad(640-895) \mu \mathrm{m} ; \quad a=22.8 \pm 1.8$ (18.5-25.6); $b=5.0 \pm 0.4 \quad(4.4-5.9) ; \mathrm{V}=54.3 \pm 1.8 \quad(50.5-57.4)$;

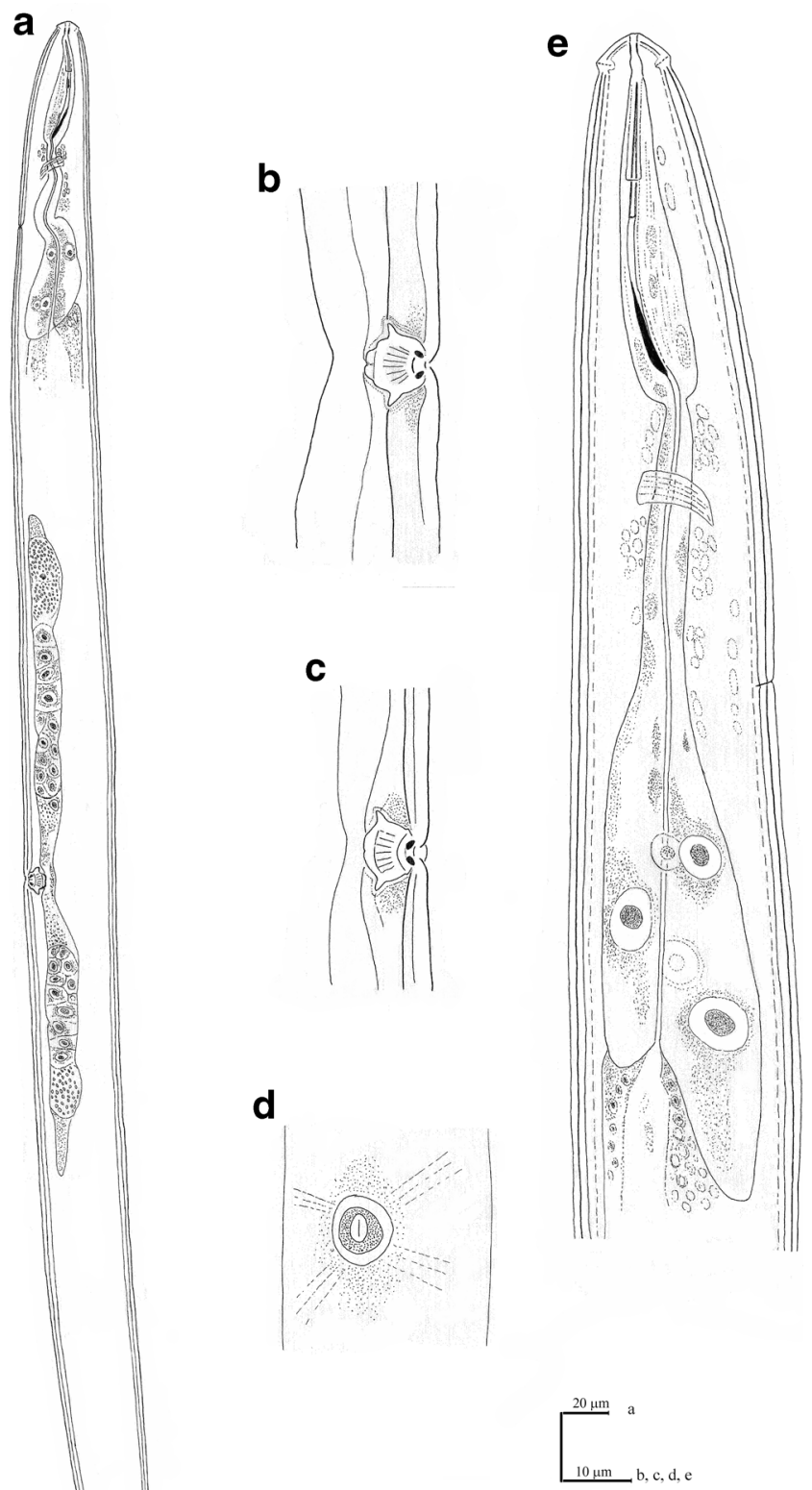

Fig. 1 Paratrichodorus teres from Iran (Female). a Total view; b and c Vaginal region; d Ventral view of vulva; e Anterior body region onchiostyle $=48.0 \pm 2.5(44.0-54.0) \mu \mathrm{m}$; anterior end to S-E pore $=102.6 \pm 5.8(95.0-114.0) \mu \mathrm{m}$; anterior end to guiding ring $=22.6 \pm 1.9(18-25)$, Karaj population $(n=12): \mathrm{L}=714 \pm$ 44.7 (649-787) $\mu \mathrm{m} ; a=20.4 \pm 1.9$ (18.0-24.7); $b=4.9 \pm 0.3$ (4.6-5.2); $\mathrm{V}=54.5 \pm 2.7$ (50.5-60.6); onchiostyle $=46.8 \pm 1.5$ $(45.0-49.0) \mu \mathrm{m}$; anterior end to S-E pore $=99.0 \pm 2.5$ $(96-102) \mu \mathrm{m}$; anterior end to guiding ring $=22.0 \pm 1.2$ (20-24).

Females largely cylindrical, almost straight when heat killed (Fig. 1a), pharynx with overlapping ventrosublateral pharyngeal glands. S-E pore opposite anterior end of pharyngeal bulb. Reproductive system didelphic-amphidelphic; uteri without sperm; vaginal sclerotizations minute, oval-shaped, well separated and oblique (Figs. $1 \mathrm{~b}$ and $2 \mathrm{~b}$ ). Vulva a short longitudinal slit (Figs. 1d and 2c), vagina with characteristic shape (Figs. $1 \mathrm{~b}$ and $\mathrm{c}$ and $2 \mathrm{~b}$ and d). Male not found.

The Iranian populations of $P$. teres closely agree in measurements and morphological features with the description of P. teres in Decraemer (1995).

Permanent slides of $P$. teres females $(\mathrm{N}=9$ : slides TPT001 and TPT002) were deposited at the Nematode Collection of the Department of Plant Protection, Karaj, Iran and $(\mathrm{N}=7$ : slides 35GO 1 and 35GO 2) at the National Nematode Collection of the Nematology Department, Iranian Research Institute of Plant protection, Tehran, Iran. Additional slides of P. teres females ( $\mathrm{N}=8$ : slides RIT822, RIT823 and RIT824) were deposited at the nematode collection of Royal Belgian Institute of Natural Sciences, Brussels, Belgium.
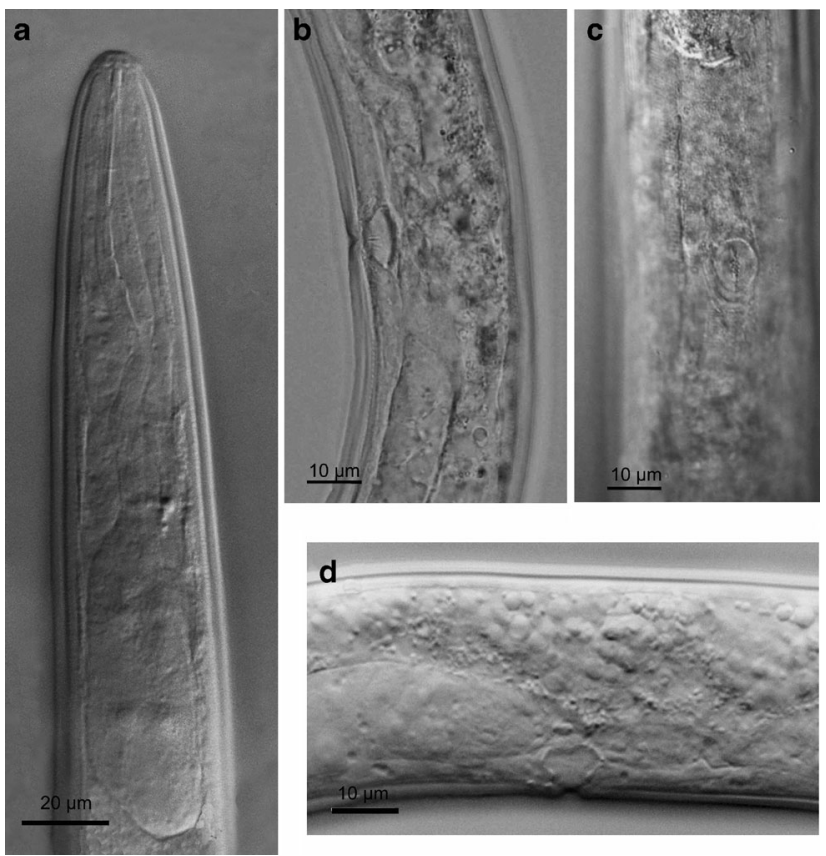

Fig. 2 Light micrographs of the female of Paratrichodorus teres from Iran. a Anterior body region; $\mathbf{b}$ and $\mathbf{d}$ Vulva region showing vagina shape; c Vulva in ventral view 
Partial amplification of the rRNA led to production of a 774 bp fragment that was deposited in the GenBank under accession number KF550304.

$P$. teres has been reported mainly from temperate regions (Decraemer 1995; Taylor and Brown 1997) although not exclusively (Karanastasi et al. 2005). The species can cause damage on host plants through direct feeding and also transmission of TRV, Tobacco Rattle Virus (Ploeg and Decraemer 1997). It is the first report of the occurrence of $P$. teres in Iran.

\section{References}

De Grisse A (1969) Redescription ou modification de quelques techniques dans L'etude des nematodes phytoparasitaires. Mede Rijks fak LandbWet Gent 34:351-369

De Waele D, Hashim Z (1983) Trichodorus orientalis n. sp. (Nematoda: Trichodoridae) from Jordan and Iran. Syst Parasitol 6:63-67

De Waele D, Sturhan D (1987) Trichodorus persicus n. sp. (Nematoda: Trichodoridae) from Iran. Syst Parasitol 10:79-83

Decraemer W (1995) The family Trichodoridae: Stubby root and virus vector nematodes. Kluwer Academic Publishers, The Netherlands

Decraemer W, Geraert E (2006) Ectoparasites. In: Perry R, Moens M (eds) Plant Nematology Wallingford. CABI publishing, UK, pp 153-184
Jenkins WR (1964) A rapid centrifugal-flotation technique for separating nematodes from soil. Plant Dis Rep 48:692

Karanastasi E, Decraemer W, Kyriakopoulou PE, Neilson R (2005) First report of the stubby-root nematode Paratrichodorus teres associated with artichoke (Cynara scolymus L.) in Greece. Plant Dis 89:685

Maafi ZT, Decraemer W (2002) Description of Trichodorus gilanensis n. sp. from a forest park in Iran and observation on Paratrichodorus tunisiensis (Siddiqi, 1963) Siddiqi, 1974 (Nematoda: Diphtherophorina). Nematology 4:43-54

Ploeg AT, Decraemer W (1997) The occurrence and distribution of trichodorid nematodes and associated tobraviruses in Europe. Nematologica 43:228-251

Pourjam E, Asghari R, Ramaji F, Heydari R (2011) Some species of plant parasitic nematodes from Iran. Iran J Plant Pathol 47:419-434

Subbotin SA, Sturhan D, Chizhov VN, Vovlas N, Baldwin JG (2006) Phylogenetic analysis of Tylenchida Thorne, 1949 as inferred from D2 and D3 expansion fragments of the 28S rRNA gene sequences. Nematology 8:455-474

Tanha Maafi Z, Subbotin S, Moens M (2003) Molecular identification of cyst-forming nematodes (Heteroderidae) from Iran and a phylogeny based on ITS-rDNA sequences. Nematology 55:99-111

Taylor CE, Brown DJF (1997) Nematode vectors of plant viruses. CAB International, Wallingford

Zahedi E, Niknam G, Decraemer W, Karegar A (2009) Trichodorus arasbaranensis $\mathrm{n}$. sp. (Nematoda: Trichodoridae) from a natural forest in Arasbaran, north-west Iran. Nematology 11:243-252 